\title{
Brand Addiction: Conceptualisation and Scale Development
}

DOI:

10.1108/EJM-10-2016-0571

\section{Document Version}

Accepted author manuscript

Link to publication record in Manchester Research Explorer

\section{Citation for published version (APA):}

Mrad, M., \& Cui, C. (2017). Brand Addiction: Conceptualisation and Scale Development. European Journal of Marketing., 51(11-12). https://doi.org/10.1108/EJM-10-2016-0571

\section{Published in:}

European Journal of Marketing.

\section{Citing this paper}

Please note that where the full-text provided on Manchester Research Explorer is the Author Accepted Manuscript or Proof version this may differ from the final Published version. If citing, it is advised that you check and use the publisher's definitive version.

\section{General rights}

Copyright and moral rights for the publications made accessible in the Research Explorer are retained by the authors and/or other copyright owners and it is a condition of accessing publications that users recognise and abide by the legal requirements associated with these rights.

\section{Takedown policy}

If you believe that this document breaches copyright please refer to the University of Manchester's Takedown Procedures [http://man.ac.uk/04Y6Bo] or contact uml.scholarlycommunications@manchester.ac.uk providing relevant details, so we can investigate your claim.

\section{OPEN ACCESS}




\section{Brand Addiction: Conceptualisation and Scale Development}

\begin{tabular}{|r|l|}
\hline Journal: & European Journal of Marketing \\
\hline Manuscript ID & EJM-10-2016-0571.R3 \\
\hline Manuscript Type: & Original Article \\
\hline Keywords: & $\begin{array}{l}\text { brand addiction, measurement scale, consumer-brand relationship, } \\
\text { addictive behaviour }\end{array}$ \\
\hline
\end{tabular}

\section{SCHOLARONE ${ }^{m}$ \\ Manuscripts}




\title{
Brand Addiction: Conceptualization and Scale Development ${ }^{*}$
}

\begin{abstract}
Purpose - We aim to develop a definition of brand addiction and a valid brand addiction scale (BASCALE).

Design/methodology/approach - We used focus-group results to define brand addiction and generate items for the BASCALE, and validated the BASCALE with survey data collected in the UK.

Findings - Based on the eleven brand-addiction features found from the focus groups, we define brand addition as an individual consumer's psychological state that pertains to a selfbrand relationship manifested in daily life and involving positive affectivity and gratification with a particular brand and constant urges for possessing the brand's products/services. Based on the survey study, we have established a valid 10-item brand addiction scale (BASCALE).
\end{abstract}

Research limitations/implications - Due to the survey's setting in the fashion context in the UK, we do not intend to generalize the results to other product types and countries. Future research should replicate and refine the BASCALE in different brand categories and different countries.

Practical implications - The BASCALE can serve marketers in the behavioral segmentation and assist brand managers to identify brand addict consumers and maintain long-term relationships with them.

Originality/value - We have developed a definition of brand addiction and a valid brand addiction scale (BASCALE), which one can use for a wide range of theoretical and empirical research in the marketing and psychology fields. The definition and BASCALE also serve to

\footnotetext{
${ }^{*}$ Note: The first authorship is shared by both authors. The authors are grateful to the associate editor and three anonymous reviewers for their helpful guidance.
} 
differentiate brand addiction from other consumer-brand relationships and addiction constructs (e.g. compulsive buying, brand love and brand trust).

Keywords brand addiction, measurement scale, consumer-brand relationship, addictive behavior.

Paper type Research paper.

13
14
15
16
17
18
19
20
21
22
23
24
25
26
27
28
29
30
31
32
33
34
35
36
37
38
39
40
41
42
43
44
45
46
47
48
49
50
51
52
53
54
55
56
57
58
59
60




\section{Brand Addiction: Conceptualization and Scale Development}

\section{Introduction}

Addictive behaviors appear in shopping, technology use, exercising, gambling, playing video games, hoarding, overeating, plastic surgery, pornography, kleptomania, dietary supplement usage, religious convictions, among others (Griffiths, 1997, 2002; Martin et al., 2013). In her seminal article on consumer-brand relationships, Fournier (1998) suggests that consumerbrand relationships may extend in intensity to the level of addiction. A recent neurophysiological study (Reimann et al., 2012) points out that close consumer-brand relationships may lead to brand addiction since there is evidence that close consumer-brand relationships are associated with activating an individual's brain area known as the insula, and activating the insula is responsible for addictive behaviors such as alcohol addiction (Myrick et al., 2004) and nicotine addiction (McClernon et al., 2005).

A prevailing perspective on addictive behavior associates it with drug/alcohol addictions and typical characteristics of the clinical definition of addiction: “... dysfunctions in brain reward, motivation, memory, and related circuitry that lead to biological, psychological, social and spiritual manifestations" (American Psychiatric Association, 2000). Fournier and Alvarez (2013) report some negative aspects of addictive consumer-brand relationships by drawing on Hirschman's (1992) study of drug addicts and alcoholics. To draw an inference from drug and/or alcohol addiction about brand addiction demands empirical and theoretical support, which is lacking in the extant literature. Some scholars point out that the word "addiction" should not be exclusively linked to drug habits since linking this term solely to drugs "creates an artificial distinction that strips the language of a term for the same condition when drugs are not involved" (Alexander and Schweighofer, 1988, p. 154). Indeed, addictions should be understood in domains beyond substance abuse (Martin et al. (2013) 
since "any source which is capable of stimulating an individual, could become addictive" (Alavi et al., 2012, p. 291). Knowledge on meanings of concepts that represent human cognition, affect and action is paramount for understanding the interrelations among the concepts. Our knowledge on consumer brand relationship is incomplete without a formal account of the meaning and measurement of brand addition beyond substance abuse. To fill in this important gap, in the current paper we aim to develop a conceptual definition and measurement scale of brand addiction. Understanding brand addiction as an extreme form of behavior will enrich our understanding of more normal consumer behaviors (O'Guinn and Faber, 1989). Further, developing a measurement instrument for new concepts can "provide building blocks for researchers attempting to develop models that explain a greater proportion of the variance in consumer behavior (Bagozzi and Burnkrant 1979; Olney, Holbrook and Batra 1991)" (Voss et al., 2003, p. 310).

Brand addiction is recognized as a salient phenomenon in the extant literature (Antonova, 2012; Fajer and Schouten, 1995; Reimann et al., 2012) and is distinct from compulsive buying. Although both may share certain common elements under the higher-order category of addictive consumption (e.g. Hirschman, 1992), such "fuzzy boundaries" do not substitute or eliminate the different essential features of the two constructs. This will be illustrated and supported in the later part of the current paper.

This paper is composed of three parts. In the first section, we provide a review of the literature from the perspectives of consumer-brand relationship and addiction. In the second section, we present the scale development and validation for the construct of brand addiction. In the last section, we discuss the findings and implications for further research and practice.

\section{Theoretical background}

Brand addiction: a form of consumer-brand relationship 
One strand of theories of consumer-brand relationships is Fournier's (1998) theory drawing from interpersonal theories to conceptualize the connection between consumers and brands along a similar continuum as in human relationships, starting from non-intense emotions to moderate emotions, friendly emotions, and passionate love, culminating in addictive obsession (Fehr and Russel, 1991; Sternberg, 1986). Fournier's (1998) empirical research shows some "dark side" relationships between the consumer and the brand, such as “dependency, enmity, enslavement, and secret affairs" (p. 361), which seem to conjecture an association with "general concepts of addiction (Hirschman, 1992)" (Fournier, 1998, p. 361). This inference suggests that consumers may develop brand addiction characterized by negative characteristics. However, Fournier's focus on the negativity of brand addictive behavior is theoretically grounded on Hirschman's (1992) study of drug addicts and alcoholics. While these "dark side" characteristics of consumer-brand relationships indicate a close link to the notion of addiction, framing the phenomenon of brand addiction in drug and alcoholic addiction may exclude some important cognitive and affect features unique to brand addiction.

A recent attachment-aversion relationship (AA Relationship) model (Fournier and Alvarez, 2013) conceptualizes consumer-brand relationships with three pairs of asset(benefit)/liability, which comprise enticing/annoying-the-self, enabling/disabling-theself, and enriching/impoverishing-the-self. The consumer-brand relationship rises to the desired level similar to human relationships when self-relevant benefits (enticing-the-self, enabling-the-self, and enriching-the-self benefits) materialize in a consumer. According to the AA model, however, Fournier's (1998) earlier conceptual base of "dark side" characteristics for brand addiction may need to be complemented by including other necessary characteristics since it is inconceivable that the addictive consumer-brand relationship is necessarily dominated by the "dark side" characteristics if such a relationship 
is stabilized by the benefits from enticing-the-self, enabling-the-self, and enriching-the-self. Moreover, Reimann et al.'s (2012) empirical findings indicate that while newly formed close consumer-brand relationships are associated with strong emotional arousal towards the brand, established close consumer-brand relationships may attenuate such an effect. This suggests that as an established close consumer-brand relationship, brand addiction may be different from other types of affect-laden consumer-brand relationships such as brand attachment and brand love. The literature on consumer-brand relationships falls short of explaining what constitutes brand addiction and how it is different from other close consumer-brand relationships. Given that consumers' addiction to brands falls within the domain of the phenomenon of addiction, it is necessary that we draw on relevant theories of addiction to explore conceptual properties of brand addiction.

\section{Brand addiction: the addiction component}

There are growing views that consumers' behavioral addiction is different in many respects from substance abuse (Alexander and Schweighofer, 1988; Martin et al., 2013; Sussman and Sussman, 2011; Young, 2004). From this perspective, behavioral addictions are considered as "compulsive psychological and physiological urges for one or more specific behaviours" (Egorov and Szabo, 2013, p. 199), which "can function both to produce gratification and to provide escape from internal discomfort", and "is employed in a pattern characterized by loss of control and continuation despite significant negative consequences" (Goodman, 1990, p. 1406). This conceptualization highlights "dependence (gratification of needs, i.e. positive reinforcement motivation) and compulsion (evasion or avoidance of internal discomfort, i.e. negative reinforcement motivation)" (p. 1407) as the inseparable features of behavioral addiction. 
In addition, Sussman and Sussman (2011) have found that as a psychological state or pattern of behavior, addiction manifests itself in five cardinal elements: (a) pursuance of some course of action for appetitive effects or motives (e.g., reducing pain, boosting affect, manipulating arousal, or fantasy); (b) preoccupation with excessive desire to perform a behavior and unrestrained time spent to organize and undertake the behavior, resulting in tolerance (i.e., the need to engage in the behavior at a relatively greater level than in the past to achieve previous levels of appetitive effects) and withdrawal (i.e., physiological or acquired discomfort experienced upon abrupt termination of an addictive behavior); (c) temporary satiation so that at times the intense desire to engage in the target addicted behavior is not functioning but will reoccur soon; (d) loss of control (i.e., the addictive behavior has become automatic); and (e) experience of negative consequences (e.g., physical discomfort, social disapproval, monetary problems, or decreased self-esteem) followed with continuing engagement in the addictive behavior. It can be assumed that the above characteristics of behavioral addiction (Goodman, 1990; Sussman and Sussman, 2011) may manifest in the behavior of brand addiction if brand addiction is regarded as similar to the general concept of addiction (Fournier, 1998).

\section{Brand addiction scale development}

In order to develop a theoretically sound conceptualization of brand addiction and a valid brand addiction measurement scale (hereinafter referred to as BASCALE), we followed Churchill's (1979) procedure for developing measures of marketing constructs. Accordingly, the following sections report on brand addiction's conceptual domain specification, item generation, scale purification, scale validation, nomological validity assessment, and scale norm development. 


\section{Conceptual domain specification}

Developing a definition for a concept under examination forms an essential part of the scale development procedure (Churchill, 1979; Gilliam and Voss, 2010). Focus groups provide an appropriate method for developing concepts and measurement items (Calder, 1977;

Churchill, 1979; DeWalt et al., 2007; Morgan, 1998; Wilkinson, 1998) because this method is effective in promoting self-disclosure of lived experiences, meanings, standings and viewpoints through the group dynamics in interaction between participants (Freeman, 2006; Wilkinson, 1998; Yin, 2016). Hence, in order to develop the definition of brand addiction and generate its measure items, we followed a rigorous procedure by using the focus-group results and critical analysis of the literature for richness and accuracy of the definitional meanings.

The focus groups. We recruited participants as a purposive sample by an invitation message on Facebook, e-mail, and public notice boards. Following Kitzinger's (1995) recommendation of group size of between 4 to 8 people, we recruited 13 females and 11 males (aged between 18-40, non-student consumers in the UK) with strong attachment to a particular brand in four focus groups (each group comprised 6 participants), and each session lasted for a maximum of two hours. We analyzed the focus group data by discursive psychology techniques (Edwards and Potter, 1992) since people experience brand addiction on a psychological basis, and discursive psychology examines how people form, interpret and reveal psychological issues in their everyday lives (Potter, 2012). Our analysis followed the recommended procedure (Potter and Whetherell, 1987; Potter, 2012; Willig, 2008): transcribing the recordings using Jefferson's (2004) method of transcription (Potter, 2012; ten Have, 1999); selecting relevant parts of the transcripts according to the thematic categories linked to the research questions (Potter and Whetherell, 1987) and coding the transcripts to 
build up the parts that require analysis (Silverman, 2011); analyzing selected excerpts of coded transcripts with reference to the research questions and focal research issues (Willig, 2008); and identifying the main themes by inferential interpretations of the data using conversational sequencing techniques, management of turn-taking, and talk overlap and repair (Hutchby and Wootfit, 2008). Due to word limitation, we only present one excerpt of coded transcripts with corresponding analysis in Table I to illustrate Jefferson's (2004) method of transcription and our interpretative analysis (all the names in this table are fictitious for anonymity).

(Place Table I here)

From the analysis of the focus-group data, we identified eleven essential features of consumer brand addiction: acquisitiveness, dependence, follow up, hoarding, lack of selfcontrol, obsession, outward influence, persistence within affordability, resistance to substitutes, support, and thought occupancy. In Table II we show these features with verbatim illustrations. In the discussion participants referred to their personal experiences relating to a range of consumer products' brands (Apple, Banana Republic, Clinique, Coke, Fendi, Hugo Boss, L’Occitane, Louis Vuitton, Monki, Mountain Dew, Mulberry, Nike, Prada, Ralph Lauren, and Rimmel). Due to the inductive nature of our analysis, we made no attempt to generalize the findings to a particular brand or product type. It is noticeable that these features were more cognitive and act-oriented than affect-laden. These features appear to be consistent with the cardinal properties of addictive relationship with brands (Goodman, 1990) and addiction (Sussman and Sussman, 2011); hence, they serve as primary information in defining the concept of brand addiction and measurement items for the brand addiction scale. Note however, that these features do not suggest harmful consequences or a 
pathological type of behavior characterized by significant interpersonal, professional, or financial difficulties. This supports our theoretical positioning to examine brand addiction outside the silo of pathological addiction such as drug and alcoholic abuse. For these reasons, our brand addiction concept and the measurement scale to be developed are not for diagnosing pathological behavior.

(Place Table II here)

At this point, the difference between brand addiction and compulsive buying can be further noticed. The features of acquisitiveness and hoarding mean that brand addicts keep a collection of items of the addictive brand even if they do not intend to use the items. In contrast, compulsive buying is potentiated by the shopping process not with the goal to acquire and accumulate the item, and compulsive buyers hide or dispose of acquired goods out of guilt or shame (Hassay and Smith, 1996). Brand addicts, however, do not feel guilt or shame. Instead, they engage in frequent thought about the brand (Thought Occupancy) and find it hard to live without their addictive brands (Dependence). Negative emotions provoke and sustain compulsive buying (Darrat et al., 2016) while brand addicts demonstrate a positive state reflected in willingness to support their addictive brands (Support) and continuously following up news about their addicted brands (Follow Up).

Defining brand addiction. A definition of brand addiction needs to be scientifically and practically useful. Among different forms of definition, the classical "definition by genus and difference" (also known as analytical definition) established by Aristotle, serves the purpose of conceptualizing brand addiction since this form of definition "designates that which makes a thing what it is and distinguishes that thing from all other things" (Corbett and Connors, 
1999, p. 33). According to this principle, a concept is defined by specifying the general class (genus) that includes the concept defined (definiendum), and the characteristics or properties (differentia) that set the concept defined (definiendum) apart from other characteristics or properties in the general class. As such, in the current study we define brand addiction (definiendum) as an individual consumer's psychological state (genus) that pertains to a selfbrand relationship manifested in daily life and involving positive affectivity and gratification with a particular brand and constant urges for possessing the brand's products/services (differentia), which can be identified by eleven essential features (acquisitiveness, dependence, follow up, hoarding, lack of self-control, obsession, outward influence, persistence within affordability, resistance to substitutes, support, and thought occupancy). We use the term "psychological state" as the genus since this term encompasses the conceptual domains for brand addiction and other forms of addiction. We also differentiate "psychological state" from other states such as mood state and physical state since the cognitive-based and act-oriented features of brand addiction is a brain state (Sussman and Sussman, 2011) that is categorically different from other kinds of state and is evidenced by the eleven essential features. For example, Reimann et al. (2012) point out that the "initial arousing period of the consumer-brand relationship may not be linear; it may increase, reach its zenith, level off, and finally decline to a more steady state" (p. 1310).

In addition, in this definition we specify brand addiction as a single (i.e., unidimensional) concept that reflects the eleven multiple attributes for domain inclusiveness and operational practicality since the eleven features include cognitive and affective manifestations that jointly reflect a basic-level typological addictive behavior centered on a "favorite brand". "Unidimensionality refers to the existence of a single trait or construct underlying a set of measures (Hattie 1985; McDonald 1981)” (Gerbing and Anderson, 1988, p. 186). Defining brand addiction at this single (unidimensional) concept level is theoretically meaningful since 
it allows brand addiction to sustain not only its unique conceptual validity but also a membership of the higher-level typologies of addictive consumption and consumer-brand relationship.

Martin et al. (2013) define addictive behavior as "characterized by the individual's lack of ability to abstain from the behaviour, lack of self-control, cravings, dysfunctional emotional responses, and inability to recognize that one's behaviour has harmful consequences (Altman et al., 1996)" (p. 1220). It is worth noting that our focus-group results did not suggest harmful consequences from brand addiction. Since the eleven essential features in the current study were derived from consumers' lived experiences in addiction to brands instead of drugs and alcohols, these essential features differentiate brand addiction from substance-abuse and other pathological addictive behavior although they belong to the broad category of addiction. Therefore, our definition of brand addiction and the measurement scale to be developed are not meant to be used for diagnosing pathological buying behavior.

At this point, it seems appropriate to lay out a holistic picture of brand addiction under the typologies of consumer-brand relationship and addictive consumption. A salient difference is in the focal reference point ("focality") between brand addiction and compulsive buying: brand addiction is focused on a specific brand while compulsive buying is focused on general buying/shopping or spending, and brand addiction expands across consumer-brand relationship and addictive consumption. While a series of patterns of addiction share some common features, addictive behaviors seem to be differentiated when weighing the degree of functional impairments resulting from the addictive behavior. In this sense, the absence of functional impairments from brand addiction differentiates it from other addictive behaviors including compulsive buying. It is therefore helpful to illustrate the typological differences between brand addiction and compulsive buying in Figure 1, and definitional differences of brand addiction and other common consumer-brand relationship constructs in Table III. 
While it is beyond the scope of the current paper to incorporate full empirical tests of the differences between brand addiction and other constructs of consumer-brand relationships, in the later part of this paper we report our empirical results of discriminant validity between brand addiction, brand love, and brand trust.

(Place Figure 1 here)

(Place Table III here)

Item generation

Based on our review of the extant literature and focus-group interviews, we generated an initial pool of 58 items to capture the conceptual domain (e.g. Churchill 1979). Then, we screened the initial 58 item statements to remove some items that were vague, repetitive, unnecessary, and otherwise faulty by following the guidelines and approaches reported in some recently published scale development studies (e.g. Freling et al., 2011). This resulted in a pool of 32 preliminary items to capture different nuances of meanings (Churchill, 1979) of brand addiction.

In order to assess content and face validity of the 32 items, we distributed the definition of brand addiction and the items to six expert judges who were experienced senior university researchers with research expertise in marketing, branding, and consumer psychology. We asked the judges to rate how relevant they believed each item was to what it was proposed to measure. Following Zaichkowsky's (1985) procedure, we asked them to indicate whether the items were "completely representative" or "not representative" of the facet of interest.

Finally, we asked them to assess the items' clarity and point out ambiguity, vagueness, double-barreled or complicated statements (Netemeyer et al., 2003; Podsakoff et al., 2012) 
and comment on any unclear items by providing suggestions on how to better clarify the statements. On the basis of the experts' feedback, we revised some item statements. Saxe and Weitz (1982) suggested that at least $50 \%$ of the judges should rate an item as completely representative in order to retain the item. Following this guideline, we reduced number of the 32 items to 29 . We asked five UK residents were to read the definition of each construct that accompanied its measurement item and to comment on any ambiguity they found. This process resulted in satisfaction with the 29 items.

\section{Scale purification}

Sampling and data collection. Since this study primarily focuses on consumers' addiction to particular brands, the unit of analysis was set at the level of the individual consumer. Since there were no prior studies of brand addiction and both consumers' brand addiction and compulsive buying are in the category of addictive consumption, we chose the sampling population for this study by an analogical reference to compulsive buying. It was reported that compulsive buying as a form of consumption addiction approximately impacts half a million adults in the UK (Dittmar, 2005). Moreover, Armstrong (2011) reported that 8-16\% of the British population (around 8 million adults) were compulsive buyers. Furthermore, researchers have reported that compulsive buying develops at the age of 18 (Schlosser et al., 1994), with the average age of compulsive buyers being between 30 and 31 years (Black et al., 2001; Schlosser et al., 1994). Accordingly, the sampling population for this study included British citizens aged between 18 and 40 with a favorite preference for at least one fashion brand.

To purify the measurement scale, we executed a pilot survey whereby 351 responses were randomly collected from British citizens through a Qualtrics online panel. In line with the British population composition (The Office for National Statistics, 2013) and using stratified 
sampling, 296 (84.33\%) of the respondents were English, 30 (8.55\%) were Scottish, 16 (4.56\%) were Welsh, and 9 (2.56\%) were Irish. Within the sampling population's age range between 18 and 40 (no control of age group distribution was attempted due to lack of prior data), the pilot survey sample showed $13.40 \%$ of the participants between 18 and 25 years of age, $49.30 \%$ between 26 and 35 , and $37.30 \%$ between 36 and 40 . One hundred and seventysix (50.14\%) were males and $175(49.85 \%)$ were females. Similar to the surveys by Batra et al. (2012), Escalas and Bettman (2003) and Thomson et al. (2005), in the current study we requested participants to enter their preference to one favorite fashion brand. Participation in the survey was anonymous. Each participant received a modest incentive in return for collaborating in completing the questionnaire. We used the 29 items that were generated from the literature and the focus groups in the survey instrument with the Likert-type scaling from "not true at all" (1) to "very true" (7).

Analysis and results. We specified the 29 BASCALE items in a unidimensional measurement model and we assessed it by confirmatory factor analysis (CFA) (Gerbing and Anderson, 1988) with LISREL 8.80 (Jöreskog and Sörbom, 2006) with the pilot sample data. Since the chi-square test is sensitive to the sample size, we assessed the measurement model fit based on the following recommended criteria: $\mathrm{RMSEA} \leq 0.08, \mathrm{NNFI} \geq 0.95, \mathrm{CFI} \geq 0.92$, and SRMR $\leq 0.08$ (Hair et al., 2010).

The first CFA run did not show satisfactory model fit. Following Gerbing and Anderson (1988) and Hair et al.'s (2010) recommendations to improve the model fit, we deleted the items that showed factor loadings below the conservative cut-off point and reassessed the model through a reiteration process. Following this process, we reduced the number of items from 29 to 13 through closely examining the estimation parameters and meanings of item statements to guard against conceptual domain attenuation from item deletion. This process 
resulted in acceptable overall goodness-of-fit measures despite the significance in chi-square: $\chi^{2}=209.62(d f=65, p<0.01), \mathrm{RMSEA}=0.08, \mathrm{NNFI}=0.98, \mathrm{CFI}=0.98, \mathrm{SRMR}=0.041$. All the factor loadings were significant and nine of the item loadings surpassed the 0.7 level suggested by Nunally (1978, p. 245) and the more conservative cut-off value of 0.5 or higher recommended by Hair et al. (2010, p. 709). The 13-item BASCALE's composite reliability was 0.928 , which was higher than the minimum recommended level of 0.60 (Fornell and Larcker, 1981). Finally, the average variance extracted (AVE) from the 13-item BASCALE was 0.54 , which was higher than the suggested cut-off value of 0.5 or higher (Fornell and Larcker, 1981). The CFA results on the factor loadings, CR and AVE provided evidence of convergent validity.

Note that the item BA1 shows a reliability (0.36) (see Table IV) that is lower than the required cut-off value of 0.4 (Hair et al., 2010; Pesämaa, Eriksson, and Hair, 2009). Given that this was a pilot study, we retained this item in the measurement scale based on content validity and model identification criteria. This decision was based on the guideline that individual indicator items with lower reliabilities are on some occasions retained in case they are considered to be important in obtaining a construct's content validity and in the overall model fit (Hair et al., 2010; Pesämaa et al., 2009),

\section{Scale validation}

Sampling and data collection. To validate the 13-item BASCALE, we conducted a survey in the context of fashion brands in the UK by randomly collecting 604 responses from British citizens through a Qualtrics online panel. Of the respondents, $506(83.3 \%)$ were English, 50 (8.3\%) were Scottish, 30 (5\%) were Welsh and 13 (3\%) were Irish. Survey participants were anonymous. They included people $18-40$ years of age with $25.7 \%$ in $18-25,39.7 \%$ in $26-35$, 
and 34.6\% in 36-40. Male participants comprised $302(50 \%)$ and $302(50 \%)$ were females. In the survey we asked participants to mark their preference for one favorite fashion brand.

In order to provide empirical evidence that brand addiction is different from other concepts in its related area, we included in this study a test of discriminant validity between brand addiction and brand love. We selected the brand love construct because both brand addiction and brand love are concepts of close consumer-brand relationships, while they focus on different psychological properties. Carroll and Ahuvia (2006) define brand love as "the degree of passionate emotional attachment a satisfied consumer has for a particular trade name" (p. 81). We adapted Carroll and Ahuvia's (2006) 10-item brand love measurement scale since it is more parsimonious than other brand love scales (e.g., Batra et al., 2012) for the practical purpose of the current study. We replaced the original two reverse-worded item statements ("I have neutral feelings about this brand" and "I have no particular feelings about this brand") with positively worded statements ("I have positive feelings about this brand" and "I have feelings towards this brand") correspondingly to avoid potential method bias. We measured the 10 items with the Likert-type scale from "not at all" (1) to "very much" (7).

Analysis and results. We randomly split the sample responses $(\mathrm{n}=604)$ into two halves: a calibration sample for developing the measurement model (adjusting it accordingly), and a validation sample for confirming the derived measurement model (DeVellis, 2012;

Diamantopoulos and Siguaw, 2000). Following the guidelines on reporting the measurement model validity (Bagozzi and Yi, 2012; Hair et al., 2010), we present the BASCALE's overall model fit, convergent and discriminant validity with the calibration sample followed by the validation sample.

We first submitted the 13-item BASCALE to CFA with the calibration sample data with the covariance matrix and the maximum likelihood estimation via LISREL 8.80. The first 
CFA run did not yield an optimal model fit. Inspections of the LISREL output showed that the lack of model fit might be due to low factor loadings for items BA9 and BA26 and suggestions to eliminate them were indicated by the modification indices. After we deleted BA9 and BA26, the resulting 11-item BASCALE's CFA demonstrated an acceptable model fit: $\chi^{2}=129.75(d f=44 ; \mathrm{p}<0.01), \mathrm{RMSEA}=0.08, \mathrm{SRMR}=0.041, \mathrm{NNFI}=0.98, \mathrm{CFI}=$ 0.98 .

Although the 11-item BASCALE fitted well with the calibration sample data, the length of the scale could be reduced for practical usage. To reduce the BASCALE's length, we adopted Voss et al.'s (2003) technique whereby the elimination of items was based on the item-tototal correlation and reliability, average variance extracted, and the $\chi^{2}$ difference calculation from confirmatory factor analysis. According to Voss et al. (2003), when the chi-square difference test between the original CFA model and the CFA of the reduced model is significant and when the AGFI increases with deleting an item, the reduced scale should be accepted. Following this process, we performed a reliability analysis and scrutinized the lowest item-to-total correlation. This revealed that item BA18 possessed the lowest item-tototal correlation 0.53 . The CFA chi-square difference test between the original 11 -item scale and the reduced 10-item scale by removing BA18 demonstrated to be significant $\left(\Delta \chi^{2}=\right.$ $129.75-96.37=33.38 ; \Delta d f=44-35=9)$. Since the new model's AGFI increased by 0.02 (AGFI with BA18 was 0.89; AGFI without BA18 was 0.91), we accepted the reduced 10item scale. After this, the AGFI value hit the plateau at 10 items and then we stopped this process. We considered the 10-item model's overall fit acceptable according to the goodnessof-fit measures: $\chi^{2}=96.37(d f=35, p<0.01), \mathrm{RMSEA}=0.08, \mathrm{NNFI}=0.98, \mathrm{CFI}=0.98$, SRMR $=0.04$. Table IV shows the 10-item BASCALE's factor loadings, item reliability, error variance, $\mathrm{CR}$, and AVE. 
(Place Table IV here)

It was observed that the item reliabilities of BA1 and BA2 were slightly lower than the cut-off point 0.40 (Hair et al., 2010; Pesämaa et al., 2009). However, their factor loadings were higher than the conservative cut-off value of 0.50 (Hair et al., 2010). Values of factor loading higher than 0.50 are normally regarded as essential for practical significance (Hair et al., 2010; Liau, Chow, Tan and Senf, 2010). Hence, we considered BA1 and BA2 retainable. The composite reliability (CR) of 0.92 and the average variance extracted (AVE) of 0.54 were higher than the suggested cut-off values (Fornell and Larcker, 1981). Accordingly, the results reported on the factor loadings, CR and AVE provided evidence of convergent validity. We retained all the 10 items (see Table IV) after assessing them with the calibration sample data.

We computed the discriminant validity between brand addiction and brand love following Fornell and Larcker's recommendations (1981) whereby we compared the AVE of each construct with the squared correlation between the constructs. We assessed the 10 -item BASCALE and Carroll and Ahuvia's (2006) 10-item brand love scale in a measurement model by CFA with the calibration sample data $(n=302)$. The CFA resulted in an unsatisfactory model fit $\left(\chi^{2}=600.11(d f=161 ; p<0.01)\right.$, RMSEA $=0.09, \mathrm{NNFI}=0.97, \mathrm{CFI}$ $=0.97$, SRMR $=0.07$ ). After deleting two poor items (the first and sixth brand love items), the CFA results showed an acceptable fit $\left(\chi^{2}=399.07(d f=134 ; p<0.01)\right.$, RMSEA $=0.08$, $\mathrm{NNFI}=0.97, \mathrm{CFI}=0.98, \mathrm{SRMR}=0.06)$. The AVE values for brand addiction $(.54)$ and brand love (.67) were greater than the value of the squared correlation (0.30), confirming discriminant validity for the two constructs.

To cross-validate the 10-item BASCALE, we performed a CFA of the 10-item measurement model with the validation sample data $(n=302)$. The cross-validation followed 
the tight replication method using identical parameter estimates between the calibration and validation sample (Diamantopoulos and Siguaw, 2000). As such, the same parameters that were retained from the measurement model analysis of the calibration sample were set in the validation measurement model. The 10-item BASCALE model's CFA analysis with the validation sample data demonstrated good overall fit: $\chi^{2}=62.01(d f=35 ; p<0.01)$, RMSEA $=0.05, \mathrm{NNFI}=0.99, \mathrm{CFI}=0.99, \mathrm{SRMR}=0.03$. The factor loadings were all above the more conservative cut-off value of 0.50 . The composite reliability (CR) of 0.91 and the average variance extracted (AVE) of 0.51 were higher than the suggested cut-off value (Fornell and Larcker, 1981). Accordingly, the results reported on the factor loadings, CR and AVE demonstrate evidence of convergent validity (see Table IV).

To cross-validate the discriminant validity of brand addiction and brand love, we assessed both constructs' scales in a CFA measurement model with the validation sample data $(n=$ 302). The CFA resulted in an unsatisfactory model fit $\left(\chi^{2}=793.23(d f=169 ; p<0.01)\right.$, $\mathrm{RMSEA}=0.11, \mathrm{NNFI}=0.95, \mathrm{CFI}=0.96, \mathrm{SRMR}=0.07)$. After deleting two poor items (the first and sixth brand love items), the CFA results showed an acceptable model fit $\left(\chi^{2}=404.72\right.$ $(d f=134 ; p<0.01), \mathrm{RMSEA}=0.08, \mathrm{NNFI}=0.97, \mathrm{CFI}=0.98, \mathrm{SRMR}=0.06)$. The AVE values for brand addiction $(0.55)$ and brand love $(0.68)$ were greater than the value of the squared correlation (0.29), confirming discriminant validity for the two constructs.

\section{Nomological validity}

We used the validation sample data $(n=302)$ to estimate nomological validity of the 10 -item BASCALE. The constructs for this test included a 4-item brand trust scale adapted from Chaudhuri and Holbrook (2001), a 5-item appearance esteem scale adapted from Hoegg et al. (2014), and the 5-item life happiness scale adopted from Diener et al. (1985). Seven-point Likert-type scales ranging from strongly disagree (1) to strongly agree (5) for all the items. 
Brand trust and brand addiction. Researchers have found that when consumers have developed trust in a brand, their feeling of the relationship with the brand is beyond the satisfaction with the brand's functional performance (Belaid and Behi, 2011). In addition, Esch et al. (2006) demonstrate that brand trust affects brand attachment. Albert et al. (2013) argue that trust can lead to the consumer's passion for the brand since brand trust is cognitive and affective by nature and has a positive impact on brand affection and brand love. Similar to other addictive behaviors that involve cognitive and emotional processes (Alexander, 2000), a consumer's addiction to certain brands involves both cognitive and emotional elements that manifest in some of the focus-group results in the current study. Therefore, trust in a fashion brand may have a positive impact on motivating consumers to become addicted to the brand. Thus, we suggest the following hypothesis:

H1: Trust in a fashion brand has a positive impact on addiction to the brand.

Brand addiction and appearance esteem. Appearance esteem is an awareness of self-worth that a person derives from his or her physical presentation (Argo and White, 2012; Pierce and Wardle, 1997). Researchers have indicated that appearance esteem is an essential source of general self-esteem (Rosen and Gross, 1987). Consumers will immerse themselves in products such as clothing to disclose who they are and consequently enhance their appearance esteem (Chowdhary and Ryan, 2003; Kaiser et al., 1991; Rosa et al., 2006). The literature demonstrates that consumers use specific products such as cosmetics and jewelry to improving their physical appearance, which leads to a stronger sense of self-worth (Hoegg et al., 2014). Since fashion brand addiction involves the excessive consumption of a brand's fashion products, consumers are expected to achieve high appearance esteem by engaging 
addictively in the consumption of fashion apparel products of addictive brands. Based on this, we propose the following hypothesis:

H2: Fashion brand addiction has a positive impact on appearance esteem.

Brand addiction and life happiness. Life happiness as a constituent of subjective well-being (Andrews and Withey, 1976) is defined as the overall assessment of the individual's life (Pavot et al., 1991). Research has indicated that establishing a close connection among people leads to happiness (Diener and Seligman, 2002). Fournier (1998) argues that the type of inter-personal relationship can also apply to the relationship that consumers establish with their favorite brands. Accordingly, the states of happiness that may result from establishing good connections among people can also transfer to the context of consumer-brand relationship. Moreover, Diener et al. (1991) argue that happiness is more heavily linked with the frequency than the intensity of people's positive emotional experiences. As indicated in the BASCALE, consumers who are addicted to a brand are more likely to feel the urge to collect items that belong to their favorite brand. Accordingly, the frequency of falling into this behavior and possessing the item from the addictive brand may positively impact the consumer's level of happiness. In addition, there is substantial evidence that owning products can enhance happiness in life (Podoshen and Andrzejewski, 2012). Based on our focus-group results, we expect that participants addicted to specific fashion brands may retain a state of happiness derived from consuming or owning the brand's products. From the focus groups findings we did not find harmful consequences as compared with some pathological addictive behavior. This is in line with Richins et al.'s (1992) argument that acquiring and owning goods improve the subjective well-being. Moreover, it is conceivable that addiction to a brand can be a manifestation of the three core components of enticing-the-self, enabling-theself, and enriching-the-self in the attachment-aversion relationship (AA Relationship) model 
(Fournier and Alvarez, 2013), which are likely to enhance one's life happiness. Therefore, we suggest the following hypothesis:

H3: Fashion brand addiction has a positive impact on life happiness.

Prior to the structural equation modeling test for the nomological validity, a CFA of all the constructs demonstrated the constructs' convergent and discriminant validity (see Table V).

The AVE and CR were all above the cut-off value. All the constructs' AVE values were greater than the squared correlations among constructs, therefore demonstrating discriminant validity among brand addiction, brand trust, appearance esteem and life happiness. In assessing the structural model based on the hypotheses, the fit indices for the structural model indicated an acceptable goodness-of-fit to the data: $\chi^{2}=704.85(d f=249, \mathrm{p}<0.01)$, RMSEA $=0.07, \mathrm{CFI}=0.95, \mathrm{NNFI}=0.94, \mathrm{SRMR}=0.14$. The model estimation demonstrated significant results for all the structural relationships. Positive relationships were supported between brand trust and brand addiction $(\gamma 1=0.38, \mathrm{t}=4.46)$, brand addiction and appearance esteem $(\beta 1=0.14, \mathrm{t}=2.18)$, and between brand addiction and life happiness $(\beta 2=0.21, \mathrm{t}=$ 2.29). Hence, the results demonstrated nomological validity of the BASCALE.

(Place Table V here)

\section{Scale norm development}

Using a raw score on a measurement scale is not informative for locating the position of a particular respondent on the measured construct (Churchill, 1979). One solution is to use the total distribution of raw scores as a set of norms based on the mean and standard deviation of the scores. There are two kinds of meanings of norms: (1) clinical meaning associated with what is acceptable, desired or required standards, or "clinical ideals", and (2) statistical 
meaning associated with the level/degree a performance is observed/recorded in relation to a defined group of other individuals (Angoff, 1984). The former requires empirical information from a "normative" or "reference" group that is representative of the measured pheromone.

Since the current study is the first of its kind in examining consumer fashion brand addiction, no prior data from normative or reference group was available for the sample selection.

Therefore, in the current paper we present the statistical-meaning-based norms, allowing a fashion brand addict's addiction level scored on BASCALE be assessed in relative terms against the norms from a sample group of fashion brands' addicts. We normalized and standardized the norm scores from the BASCALE from this study's sample $(n=604)$ by a Tscore, which is a z-score with predefined mean and standard deviation (SD) to allow one to see where a person stands in relation to everybody else (Streiner and Norman, 2008). One can achieve the T-scores by transforming the z-score using the formula

$T=\bar{X}^{\prime}+\frac{\left(S D^{\prime}\right)(X-\bar{X})}{S D}$

where $\bar{X}^{\prime}$ is the new mean that the authors want to set, and $S D^{\prime}$ is the desired standard deviation.

Following conventional practice (e.g., the Minnesota Multiphasic Personality Inventory (MMPI) and the Personality Assessment Inventory), our T-scores are defined as having a mean of 50 (corresponding to the raw scores 31-32) and SD of 10 (Streiner and Norman, 2008), which entail the T-scores between 20 and 80 assuming the scores are normally distributed. Our T-scores range between 33 and 80 suggesting a normal distribution (see Table VI). We also provide the percentiles in Table VI since percentile ranking is another way of using scale norms (e.g., Churchill, 1979). Since this is the first study of fashion brands addiction, our sample may serve as a preliminary reference group of British consumers with the T-scores as norms of fashion brand addiction for identifying clinicallybased norms in different categories in future research. 
(Place Table VI here)

\section{Discussion and implications}

Theoretical implications.

Our conceptualization of brand addiction and the BASCALE provide an important contribution to the literature of consumer-brand relationship and addictive consumption behavior. The results address some researchers' speculations about the existence of addiction to brands (e.g., Park et al., 2013; Reimann et al., 2012), and confirm that researchers can empirically identify consumers' addictive behavior towards particular brands. Moreover, the discriminant validity established in the current study provides evidence that brand addiction is theoretically distinct from another close consumer-brand relationship - brand love. The results from the current research have several theoretical implications. First, our extensive review of the literature on consumer-brand relationship and addiction demonstrates that brand addiction is a newly emerged concept but it has not been defined previously. Thus, researchers can use our definition of brand addiction to identify this type of consumer behavior and build theoretical models in the areas of marketing, consumer behavior/psychology, behavioral addiction and psychiatry. Second, the features of brand addiction found from the focus groups can benefit future research in further exploring the "fuzzy boundaries" across consumer-brand relationships and addictive consumption behaviors. Third, in this research we have presented the brand addiction scale (BASCALE) as a reliable and valid instrument for measuring brand addiction for further research in the fields of consumer-brand relationships. In response to Swimberghe et al.'s (2014) call for further studies to investigate consumer-brand relational constructs, the conceptualization of 
brand addiction with the empirical support for the BASCALE in the current paper is an important step forward in this direction.

\section{Managerial implications}

Marketers (especially branding managers) can use the BASCALE developed in the current paper to classify their consumers and effectively segment their markets. The BASCALE may prove useful in the behavioral segmentation and other marketing research areas since it is a short, valid, and easy-to-administer measurement tool. The use of the BASCALE can assist branding managers in exploring and detecting consumers who are truly addicted to their brands, measuring the prominence and dynamics of the phenomenon on consumers' purchase behavior of their branded products, and examining the interaction between brand addiction and diverse marketing activities. As such, we recommend marketing managers, fashion retailers and marketing researchers to utilize the BASCALE to identify brand addict consumers, better understand them, and establish and maintain long-term relationships with them.

\section{Limitations and future research directions}

The first limitation in this research lies in the examination of consumers' brand addiction exclusively in the fashion context in the UK. This limits the generalizability of the findings from the current research to wider populations and other product types. Further research could examine brand addiction in different brand categories and test BASCALE with samples of different countries. In the current study, we assessed the BASCALE's discriminant and nomological validity with a small number of constructs. Future research should test the BASCALE with other types of consumer-brand relationship (brand attachment, brand liking, brand love, brand loyalty brand passion, and brand trust). The sample size of 604 respondents 
is relatively small compared to the estimated $19,489,600$ British citizens between the ages of 18 and 40. Future research should use a larger sample to replicate the findings from the current study.

We recommend future research to explore the possible shared elements of the "fuzzy boundaries" and differences across different types of addictive consumption. Since addictive behaviors have consequences that differ from those of normal consumption behaviors (e.g., Faber and O'Guinn, 1989), we suggest future research to examine how brand addiction can function in an integrated framework with its antecedents and consequences that may involve brand love, brand loyalty, and brand passion, among other important factors, to provide important insight into the area of consumer behavior. Although in the current research we have not identified negative consequences of brand addiction, we encourage future research to explore possible conditions under which brand addiction might involve some negative effects on consumers' well-being since researching the negative aspects of consumer behavior is necessary to provide a full understanding of the field of consumption (Faber and O’Guinn, 1988; Moschis and Cox, 1989).

\section{References}

Alavi, S.S., Ferdosi, M., Jannatifard, F., Eslami, Mehdi, Alaghemandan, H. and Setare, M. (2012), "Behavioral addiction versus substance addiction: Correspondence of psychiatric and psychological views", International Journal of Preventive Medicine, Vol. 3 No. 4, pp. 290-294.

Albert, N., Merunka, D. and Valette-Florence, P. (2010), "Passion for the brand and consumer brand relationships", in Proceedings of the Australian and New Zealand Marketing Academy Conference, New Zealand, pp. 1-9. 
Albert, N., Merunka, D., and Valette-Florence, P. (2013), "Brand passion: Antecedents and consequences”, Journal of Business Research, Vol. 66 No. 7, pp. 904-909.

Alexander, B. (2000), “The globalization of addiction”, Addiction Research, Vol. 8 No. 6, pp. $501-526$

Alexander, B.K. and Schweighofer, A.R.F. (1988), "Defining addiction”, Canadian Psychology, Vol. 29 No. 2, pp. 151-163.

Altman, D. G., Levine, D. W., Coeytaux, R., Slade, J. and Jaffe, R. (1996), “Tobacco promotion and susceptibility to tobacco use among adolescents aged 12 through 17 years in a nationally representative sample”, Psychopharmacology, Vol. 86 No. 11, pp. $1590-1593$.

American Psychiatric Association (2000), Diagnostic and Statistical Manual of Mental Disorders DSM-IV-TR (4th ed.), American Psychiatric Association, Arlington. Andrews, F.M. and Withey, S.B. (1976), Social Indicators of Well-Being, Plenum, New York.

Angoff, W.H. (1984), Scales, Norms, and Equivalent Scores, Educational Testing Service, Princenton, New Jersey.

Anselmsson, J., Johansson, U. and Persson, N. (2008), “The battle of brands in the Swedish market for consumer packaged food: A cross-category examination of brand preference and liking”, Journal of Brand Management, Vol. 16 No. 1, pp. 63-79.

Antonova, N. (2012), "Perceiving brand's personality: Gender aspects", paper presented at Athens Institute for Education and Research: ATINER's Conference Paper Series PSY2012-0151, 7 September, Greece, Crete available at: https://www.hse.ru/pubs/share/direct/document/76726969 (accessed 01 March 2017). 
Argo, J.J. and White, K. (2012), "When do consumers eat more? The role of appearance selfesteem and food packaging cues”, Journal of Marketing, Vol. 76 No. 2, pp.67-80.

Armstrong, A. (2011). "How to cure shopping addiction", available at: http://www.theguardian.com/sustainable-business/how-to-cure-shopping-addiction (accessed 9 December, 2016).

Bagozzi, R.P and Burnkrant, R.E. (1979), “Attitude organization and the attitude-behavior relationship", Journal of Personality and Social Psychology, Vol. 37 No. 6, pp.913929.

Bagozzi, R.P. and Yi, Y. (2012), "Specification, evaluation, and interpretation of structural equation models", Journal of the Academy of Marketing Science, Vol. 40 No. 1, pp. 834.

Batra, R., Ahuvia, A. and Bagozzi, R.P. (2012), "Brand love”, Journal of Marketing, Vol. 76 No. 2, pp. 1-16.

Belaid, S. and Behi, A.T. (2011), "The role of attachment in building consumer-brand relationships: An empirical investigation in the utilitarian consumption context”, Journal of Product and Brand Management, Vol. 20 No. 1, pp. 37-47.

Black, D.W., Monahan, P., Schlosser, S. and Repertinger, S. (2001), “Compulsive buying severity: An analysis of compulsive buying scale results in 44 subjects", The Journal of Nervous and Mental Disease, Vol. 189 No. 2, pp. 123-126.

Calder, B.J. (1977), "Focus groups and the nature of qualitative marketing research", Journal of Marketing Research, Vol. 14 No. 3, pp. 353-364.

Carroll, B.A. and Ahuvia, A.C. (2006), "Some antecedents and outcomes of brand love", Marketing Letters, Vol. 17 No. 2, pp. 79-89. 
Chaudhuri, A. and Holbrook, M.B. (2001), “The chain of effects from brand trust and brand affect to brand performance: The role of brand loyalty", Journal of Marketing, Vol. 65 No. 2, pp. 81-93.

Chowdhary, U. and Ryan, L. (2003), "Self-esteem and apparel staisfaction with appropriate clothing: Value of product attributes and support groups for mastectomy survivors", Perceptual and Motor Skills, Vol. 97 No. 1, pp.35-44.

Churchill Jr, G.A. (1979), “A paradigm for developing better measures of marketing constructs", Journal of Marketing Research, Vol. 16 No. 1, pp. 64-73.

Corbett, E.P.J. and Connors, R.J. (1999), Classical Rhetoric for the Modern Student, Oxford University Press, Oxford.

Darrat, A.A., Darrat, M.A. and Amyx, D. (2016), "How impulse buying influences compulsive buying: The central consumer anxiety and escapism”, Journal of Retailing and Consumer Services, Vol. 31, pp.103-108.

DeVellis, R. (2012), Scale Development: Theory and Applications, Sage Publications, Thousand Oaks, CA.

DeWalt, D.A., Rothrock, N., Yount, S. and Stone, A.A. (2007), "Evaluation of item candidates: The PROMIS qualitative item review", Medical Care, Vol. 45 No. 5, pp. S12-S21.

Diamantopoulos, A. and Siguaw, J. (2000). Introducing LISREL, Sage Publications, London, England.

Diener, E. and Seligman, M. E. (2002), "Very happy people”, Psychological Science, Vol. 13 No. 1, pp. 81-84. 
Diener, E., Sandvik, E. and Pavot, W. (1991), “Happiness is the frequency, not the intensity, of positive versus negative affect", Subjective Well-Being: An Interdisciplinary Perspective, Vol. 21, pp. 119-139.

Diener, E.D., Emmons, R.A., Larsen, R.J. and Griffin, S. (1985), “The satisfaction with life scale", Journal of Personality Assessment, Vol. 49 No. 1, pp. 71-75.

Dittmar, H. (2005), “Compulsive buying-a growing concern? An examination of gender, age, and endorsement of materialistic values as predictors", British Journal of Psychology, Vol. 96 No. 4, pp. 467-491.

Edwards, D. and Potter, J. (1992), Discursive Psychology, Sage Publications, London, England.

Egorov, A.Y. and Szabo, A. (2013), "The exercise paradox: An interactional model for a clearer conceptualization of exercise addiction", Journal of Behavioral Addictions, Vol. 2 No. 4, pp. 199-208.

Escalas, J.E. and Bettman, J.R. (2003), "You are what they eat: The influence of reference groups on consumers' connections to brands", Journal of Consumer Psychology, Vol. 13 No. 3, pp. 339-348.

Esch, F-R., Langner T., Schmitt, B.H. and Geus P. (2006), “Are brands forever? How brand knowledge and relationships affect current and future purchases", Journal of Product \& Brand Management, Vol. 15 No. 2, pp. 98-105.

Faber, R.J. and O’Guinn, T.C. (1988), “Expanding the View of Consumer Socialization: A Nonutilitarian Mass-mediated Perspective”, in Hirschman E.C. and J.N. Sheth (Ed.), Research in Consumer Behavior, Greenwich, CT: JAI, pp. 49-77. 
Faber, R.J. and O’Guinn, T.C. (1989), “Classifying compulsive consumers: Advances in the development of a diagnostic tool", Advances in Consumer Research, Vol. 16 No. 1, pp. $738-744$.

Fajer, M. T. and Schouten, J. W. (1995), “Breakdown and dissolution of person-brand relationships", Advances in Consumer Research, Vol. 22 No. 1, pp. 663-667.

Fehr, B. and Russell J.A. (1991), “The concept of love viewed from a prototype perspective”, Journal of Personality and Social Psychology, Vol. 60 No. 3, pp. 425- 43.

Fornell, C. and Larcker, D.F. (1981), "Evaluating structural equation models with unobservable variables and measurement error", Journal of Marketing Research, Vol. 18 No. 1 , pp. $39-50$.

Fournier, S. (1998), “Consumers and their brands: Developing relationship theory in consumer research”, Journal of Consumer Research, Vol. 24 No. 4, pp. 343-353.

Fournier, S. and Alvarez, C. (2013), "Relating badly to brands", Journal of Consumer Psychology, Vol. 23 No. 2, pp. 253-264.

Freeman, T. (2006), “'Best practice’ in focus group research: making sense of different views", Journal of Advanced Nursing, Vol. 55 No. 5, pp.491-497.

Freling, T.H., Crosno, J.L. and Henard, D.H. (2011), "Brand personality appeal: Conceptualization and empirical validation", Journal of the Academy of Marketing Science, Vol. 39 No. 3, pp. 392-406.

Gerbing, D.W. and Anderson, J.C. (1988), “An updated paradigm for scale development incorporating unidimensionality and its assessment", Journal of Marketing Research, Vol. 25, pp. 186-192. 
Gilliam, D. and Voss, K. E. (2010), “A proposed procedure for construct definition in marketing”, in Brady M. K. and M. D. Hartline (Eds.), 2010 AMA Winter Educator's Conference, American Marketing Association, Chicago.

Goodman, A. (1990), “Addiction: Definition and implications”, British Journal of Addiction, Vol. 85 No. 11, pp. 1403-1408.

Griffiths, M.D. (1997), “Exercise addiction: A case study”, Addiction Research and Theory, Vol. 5 No. 2, pp. 161-168.

Griffiths, M.D. (2002). Gambling and Gaming Addictions in Adolescence, British Psychological Society/ Blackwells, Leicester, England.

Hair Jr JF, Babin, B., and Anderson, R. (2010), Multivariate Data Analysis, Pearson Education, Upper Saddle River.

Hassay, D.N. and Smith, M.C. (1996), “Compulsive buying: An examination of the consumption motive", Psychology \& Marketing, Vol.13 No.8, pp.741-752.

Hattie, John (1985), "Methodology Review: Assessing Uni-dimensionality of Tests and Items," Applied Psychological Measurement, 9 (June), 139-64.

Hirschman, E.C. (1992), “The consciousness of addiction: Toward a general theory of compulsive consumption”, Journal of Consumer Research, Vol. 19 No. 2, pp. 155179.

Hoegg, J., Scott, M.L., Morales, A.C. and Dahl, D.W. (2014), “The flip side of vanity sizing: How consumers respond to and compensate for larger than expected clothing sizes”, Journal of Consumer Psychology, Vol. 24 No.1, pp. 70-78.

Hutchby, I. and Wooffitt, R. (2008), Conversation Analysis. Polity Press, Cambridge. Jefferson, G. (2004), “Glossary of transcript symbols with an introduction”, Pragmatics and Beyond New Series, Vol. 125, pp. 13-34. 
Jöreskog, K.G., and Sörbom, D. (2006). Lisrel 8.8: Interactive LISREL: Technical Support, Scientific Software, Lincolnwood.

Kaiser, S.B., Nagasawa, R.H. and Hutton, S.S. (1991), "Fashion, postmodernity and personal appearance: A symbolic interactionist formulation”, Symbolic Interaction, Vol. 4 No. 2, pp. $165-185$.

Kitzinger, J. (1995), “Qualitative research. Introducing focus groups”, BMJ: British Medical Journal, Vol. 311 No. 7000, pp. 299-302.

Liau, A. K., Chow, D., Tan, T. K. and Senf, K. (2010), “Development and validation of the personal strengths inventory using exploratory and confirmatory factor analyses", Journal of Psychoeducational Assessment, Vol. 21 No.9, pp. 14-26.

Martin, I.M, Kamins, M.A, Pirouz, D.M., Davis, S.W., Haws, K.L., Mirabito, A.M., Mukherjee, S., Rapp, J.M. and Grover, A. (2013), “On the road to addiction: The facilitative and preventive roles of marketing cues", Journal of Business Research, Vol. 66 No. 8, pp. 1219-1226.

McClernon, F., Hiott, F., Huettel, S. and Rose, J. (2005), “Abstinence-induced changes in self-report craving correlate with event-related FMRI responses to smoking cues", Neuropsychopharmacology, Vol. 30 No. 10, pp. 1940-1947.

McDonald, R.P. (1981), “The Dimensionality of Tests and Items,” British Journal of Mathematical and Statistical Psychology, 34 (May), 100-17.

Morgan, D.L. (1998). Planning Focus Groups, Sage Publication, Thousand Oaks, London, New Delhi.

Moschis, G.P. and Cox, D. (1989), "Deviant consumer behavior”, Advances in Consumer Research, Vol. 16 No. 1, pp. 732-737. 
Myrick, H., Anton, R. F., Li, X., Henderson, S., Drobes, D., Voronin, K. and George, M. S. (2004), "Differential brain activity in alcoholics and social drinkers to alcohol cues: Relationship to craving”, Neuropsychopharmacology, Vol. 29 No. 2, pp. 393-402.

Netemeyer, R.G., Bearden, W.O. and Sharma, S. (2003), Scaling Procedures: Issues and Applications, Sage Publications: California, U.S.

Nunally, J.C. (1978), Psychometric Theory, $2^{\text {nd }}$ edition, McGraw-Hill Book Company, New York, NY.

O'Guinn, T.C. and Faber R.J. (1989), “Compulsive buying: A phenomenological Exploration”, Journal of Consumer Research, Vol. 16 No. 2, pp. 147-157.

Olney, T.J., Holbrook, M.B. and Batra, R. (1991), “Consumer responses to advertising: the effects of ad content, emotions, and attitude toward the ad on viewing time", Journal of Consumer Research, Vo. 17 No. 4, pp.440-453.

Park, C.W., Eisingerich, A.B. and Park, J.W. (2013), “From brand aversion or indifference to brand attachment: Authors' response to commentaries to Park, Eisingerich, and Park's brand attachment-aversion model", Journal of Consumer Psychology, Vol. 23 No. 3, pp.269-274.

Park, W. C., MacInnis, D. J., Priester, J., Eisingerich, A. B. and Iacobucci, D. (2010), "Brand attachment and brand attitude strength: Conceptual and empirical differentiation of two critical brand equity drivers", Journal of Marketing, Vol. 74 No. 6, pp. 1-17.

Pavot, W., Diener, E., Colvin, C.R. and Sandvik, E. (1991), "Further validation of the satisfaction with life scale: Evidence for the cross-method convergence of well-being measures", Journal of Personality Assessment, Vol. 57 No. 1, pp. 149-161. 
Pesämaa, O., Eriksson, P.E. and Hair, J.F. (2009), "Validating a model of cooperative procurement in the construction industry", International Journal of Project Management, Vol. 26 No.1 6, pp. 552-559.

Pierce, J.W. and Wardle, J. (1997), “Cause and effect beliefs and self $\square$ esteem of overweight children”, Journal of Child Psychology and Psychiatry, Vol. 38 No. 6, pp. 645-650.

Podoshen, J.S. and Andrzejewski, S.A. (2012), “An examination of the relationships between materialism, conspicuous consumption, impulse buying, and brand loyalty", Journal of Marketing Theory and Practice, Vol. 20 No. 3, pp. 319-334.

Podsakoff, P.M., MacKenzie, S.B. and Podsakoff, N.P. (2012), "Sources of method bias in social science research and recommendations on how to control it", Annual Review of Psychology, Vol. 63, pp. 539-569.

Potter, J. (2012). "Discourse analysis and discursive psychology”, in Cooper, H. APA handbook of Research Methods in Psychology, American Psychological Association Press, Washington, pp. 111-130.

Potter, J. and Wetherell, M. (1987), Discourse and Social Psychology: Beyond Attitudes and Behavior, Sage Publications, London, England.

Reimann, M., Castaño, R., Zaichkowsky, J. and Bechara, A. (2012), "How we relate to brands: Psychological and neurophysiological insights into consumer-brand relationships", Journal of Consumer Psychology, Vol. 22 No. 1, pp. 128-142.

Richins, M.L., McKeage, K.K. and Najjar, D. (1992), “An exploration of materialism and consumption-related affect", Advances in Consumer Research, Vol. 19 No. 1, pp. 229236. 
Rosa, J.A., Garbarino, E.C. and Malter, A.J. (2006), “Keeping the body in mind: The influence of body esteem and body boundary aberration on consumer beliefs and purchase intentions", Journal of Consumer Psychology, Vol. 16 No. 1, pp. 79-91.

Rosen, J.C. and Gross, J. (1987), "Prevalence of weight reducing and weight gaining in adolescent girls and boys", Health Psychology, Vol. 6 No. 2, pp. 131-147.

Saxe, R. and Weitz, B.A. (1982), "The SOCO scale: A measure of the customer orientation of salespeople”, Journal of Marketing Research, Vol. 19 No. 3, pp. 343-351.

Schlosser, S., Black, D. W., Repertinger, S. and Freet, D. (1994), “Compulsive buying: Demography, phenomenology, and comorbidity in 46 subjects”, General Hospital Psychiatry, Vol. 16 No. 3, pp. 205-212.

Silverman, D. (2011), Qualitative Research, Sage Publication, Thousand Oaks.

Sternberg, R.J. (1986), “A triangular theory of love”, Psychological Review, Vol. 93 No. 2, pp. 119-135.

Streiner, D.L. and Norman, G.R. (2008), Health Measurement Scales: A Practical Guide to Their Development and Use, 4th Edition, Oxford University Press.

Sussman, S. and Sussman, A. N. (2011), "Considering the definition of addiction", International Journal of Environmental Research and Public Health, Vol. 8 No. 10, pp. $4025-4038$.

Swimberghe, K.R., Astakhova, M. and Wooldridge, B.R. (2014), “A new dualistic approach to brand passion: Harmonious and obsessive", Journal of Business Research, Vol. 67 No. 12 , pp. 2657-2665.

ten Have, P. (1999), Doing Conversation Analysis: A Practical Guide, Sage Publications, Thousand Oaks. 
The Office for National Statistics. (2013), "Population estimates for UK, England and Wales, Scotland and Northern Ireland, Mid-2011 and Mid 2012” available at http://www.ons.gov.uk/ons/publications/re-reference-tables.html?edition=tcm\%3A77319259 (accessed 10 December, 2013).

Thomson, M., MacInnis, D.J. and Whan P.C. (2005), "The ties that bind: Measuring the strength of consumers' emotional attachments to brands", Journal of Consumer Psychology, Vol. 15 No. 1, pp. 77-91.

Voss, K.E., Spangenberg, E.R., and Grohmann, B. (2003), “Measuring the hedonic and utilitarian dimensions of consumer attitude”, Journal of Marketing Research, Vol. 40. No. 3, pp. 310-320.

Wilkinson, S. (1998), "Focus group methodology: A review”, International Journal of Social Research Methodology, Vol. 1 No. 3, pp. 181-203.

Willig, C. (2008), Introducing Qualitative Research in Psychology: Adventures in Theory and Method, McGraw-Hill Education, Maidenhead.

Yin, R.K. (2016), Qualitative Research from Start to Finish, The Guilford Press, New York. Young, K.S. (2004), "Internet addiction a new clinical phenomenon and its consequences", American Behavioral Scientist, Vol. 48 No. 4, pp. 402-415.

Zaichkowsky, J.L. (1985), "Measuring the involvement construct”, Journal of Consumer Research, Vol. 12 No. 3, pp. 341-352. 


\section{Table I.}

An example of focus-group discursive psychology analysis

1- Moderator: But he doesn't buy from ozer brands other than Hugoo Bosss

2- Paul: No? [w::]

3- Carol: [No?whhh]

4- Marc: = What I have uhhh consist of eighry percent Hugoo Boss and the ozer:: than let us say ten or fifteen percent will be like Ralph Laureyn and $>$ [the other as (.) well<]

\section{5- Natasha:}

[Maybay: Hugo Boss design design covers]

6- Paul: $\quad=$ Ya $>$ becoz: hez such inaddict he haz influenced me as well [that no?w at this no?w bcoz] $=$

This excerpt is taken from one of the focus groups when the discussion was about the number of items that the participants gathered from a particular brand. During this conversation, the moderator probed the participants by asking whether Marc ("he" in line 1) bought any brands other than Hugo Boss (line 1). Paul and Carol directly stated "no" by self-selecting themselves (lines 2 and 3). As a form of turn taking, self-selection is a procedure during which a succeeding participant puts him-/herself forward to take the turn. The answers from Paul and Carol indicate that Marc didn't purchase any other brands. Then, Marc interfered to explain but not to disagree with the "no" answers from Paul and Carol. Marc stated that his wardrobe consisted of $80 \%$ of Hugo Boss with the rest being from Ralph Lauren or other brands (line 4). According to Edwards and Potter (1992), the reliability of a certain report will be justified by the claims of the category membership of talkers. In this discussion, Paul was Marc's brother and Carol was Marc's friend, hence, Paul and Carol belonged to the family and friendship categories. They were supposed to know about the behavior of the people who were in this category. Therefore, the reliability of the claim about Marc's tendency to possess a collection of addictive brand's products (i.e., Hugo Boss) was confirmed in accordance with the three members. Taking into account some transcripts from other groups (not displayed here) showing the similar theme, an inference of "hoard" from this tendency as an essential feature of brand addiction ensued. 
Table II.

Features of brand addiction found from the focus groups

\section{Essential Descriptions \\ Features}

Acquisitiveness

Brand addict consumers tend to buy addictive brand's items even if they do not have the need for them and are not going to use them in the near future.

"You can confuse what you want from what you need when you are addicted, I convince myself that I need it when I don't need it."

"You know some of them may overlap and you don't necessarily need an iPad or an iPhone and a MacBook but someone who have all of them just to say I have got all of them."

"Oh God I have got an addiction, yeah yeah ...because I do buy stuff I don't need."

Dependence $\quad$ Brand addict consumers find it hard for them to live without their addicted brands.

"I cannot live without clinic products, I have got basically the whole set the morning wake up, the cleanser, the moisturizer, day cream, night cream."

Follow up Brand addict consumers appear to continuously follow up news about their addicted brands.

"... I follow it all the time, I follow the new collection, spring, summer."

"I work from Monday to Friday so I don't have time to go shopping and I don't have time basically to go malls and, but Saturday, Sunday I make sure to visit even if I don't buy a Prada bag; it satisfies me the moment I enter the shop and just look around and just check prices and check different colors."

"You know apple is a sort of secretive company, I found out that everyday, even if it is on, what we call it, mmm, browser on my book mark, it is this apple website that I read everyday, so I basically know what is going on every day. Even now I know that the next IPhone is going to come out 10th of September."

Hoarding Individuals addicted to a particular brand have the tendency to possess a collection of their addicted brands' products.

"And on the high end I will put diehard, it is someone who will have an iPhone, who will have a MacBook, will have an iPad, you know."

"I have got the orange one, red one, black, I have got the white and red, I have got the dark blue and I have got the off-white, that is so far."

Lack of selfcontrol

Brand addict consumers usually fail to control themselves from visiting their addicted brands' shops whenever they pass by it.

“... addiction manifests in the way that I can not ignore not to enter into their shop when I am passing by, I can not control myself not to check their website at least 3-4 times a week, I would love to go and probably have all the shop in my house."

Obsession Consumers addicted to particular brands tend to be obsessed with getting everything created and produced by their addicted brand.

"What I have got as clothing consist of eighty percent of Hugo Boss."

"Because when he thinks of shoes this brand comes as Louis Vuitton, He think of belts it comes Louis Vuitton, if he thinks of ... even a watch he thinks of Louis Vuitton anld even the luggage, the suit cases, laptops, bags any damn thing Louis Vuitton."

Outward influence
Brand addicted consumers are most likely to influence other people to purchase their addicted brands' products.

"I try to influence people all the time, I try to give my friends, I don't know if that is 
because of addiction or I want people to run with me, but, and compete on this Nike thing... I will not necessarily push people to Nike but I would say oh you wear Adidas." "... myself apart from bags, mmm I am a big follower of clinic products and I am trying to influence my friends to use it."

Persistence within Brand addict consumers tend to persist in buying their addicted brands as long as they can affordability afford them. The findings reveal that none of the participants would incur any debts to purchase their addicted brands, which suggests that they will most likely save a certain percentage of their monthly income to purchase the items from their addicted brands.

"I have got bags from very cheap bags but when I feel I can afford buying at least expensive bag that I like I just go for Prada."

"... no they can not afford but they are diehard so they will still find other means like eBay..."

"When I can not afford it, I have to go to the shop like whenever we go to Piccadilly, I have to go to Fendi and look at it, then I feel happy."

Resistance to substitutes

Brand addict consumers tend to continue to buy items from their addicted brands even when similar products are available at a lower price under a different brand. The situation in which an individual agrees to try other brands only occurs when his/her addicted brand is removed from the market.

"... you might not get from another brand and that might be better for you because you are stuck in (your addictive brand)"

"They already doubled the price a few years ago and I am still buying it."

Support Brand addict consumers have the willingness to support their favorite brands. For example, some focus-group participants mentioned that they were ready to incur financial investments to support their favorite brands.

“... bought their stock regardless of the situation they were in because I was that committed to Apple and I knew that they can use my money that I put in their research and development to better my relationship with them."

Thought Brand addict consumers engage in frequent thoughts about the brand. occupancy

"I get updates on my phone about apple, like I get push notifications about apple news, about what their stocks doing, about." 


\section{Figure 1.}

A holistic view of brand addiction

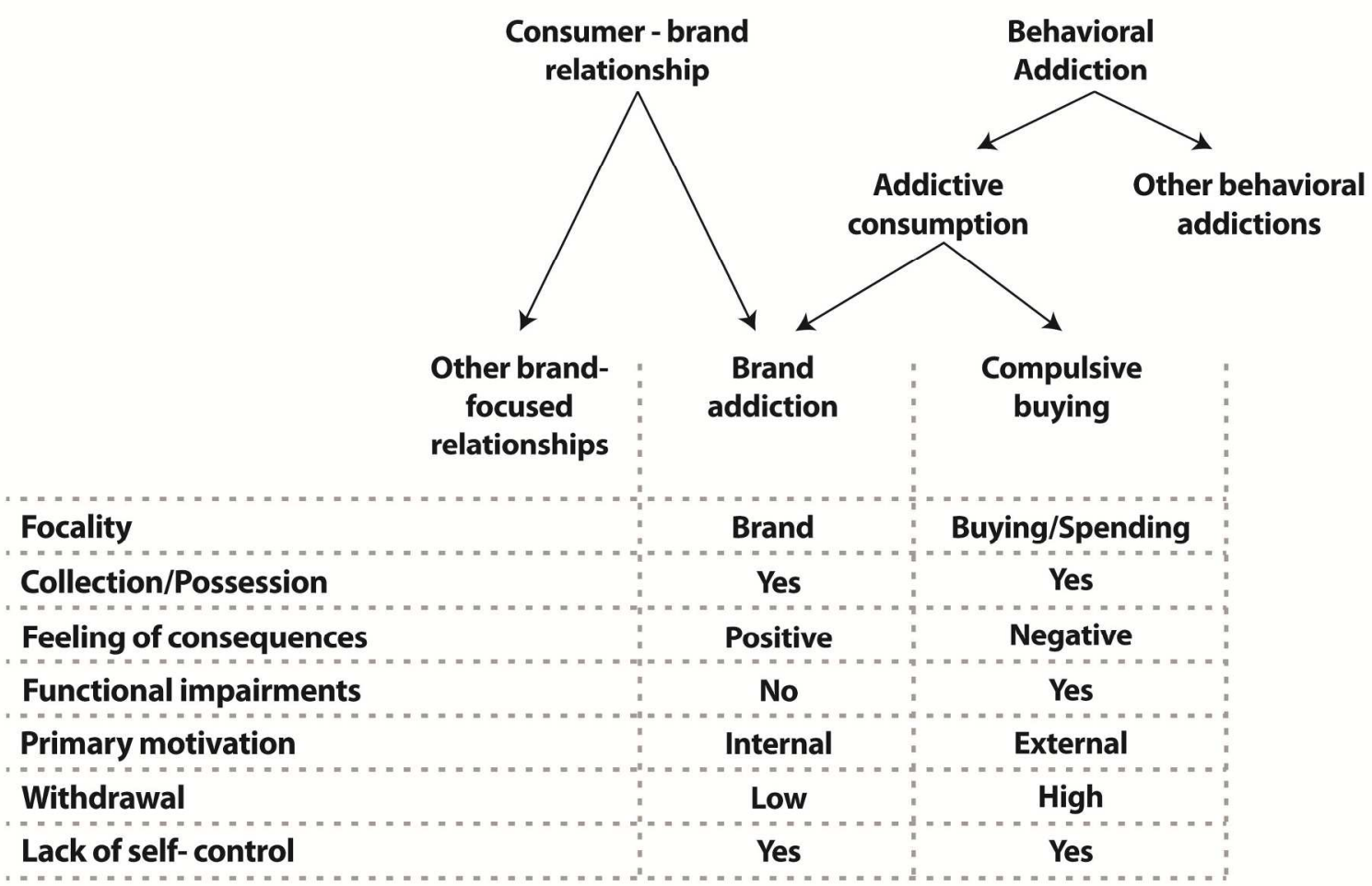




1
2
3
4
5
6
7
8
9
10
11
12
13
14
15
16
17
18
19
20
21
22
23
24
25
26
27
28
29
30
31
32
33
34
35
36
37
38
39
40
41
42
43
44
45
46
47
48
49
50
51
52
53
54
56
50 \\ Page 43 of 48}

1

4

5

6
7

8

10

11

12

14

15

16

18

19

20

22

23

25

26

27

29

30

32

33

34

35
36

37

38

39

40

41

42

44

45

46

47

48

49

51

52

53
54

55

56

57

58
59

60 
Table III.

Definitions of consumer-brand relationships and compulsive buying

Brand addiction

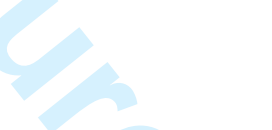

Brand Attachment

Brand Liking

Brand Love

Brand Loyalty

Brand Passion

Brand Trust

Compulsive Buying
An individual consumer's psychological state that pertains to a self-brand relationship manifested in daily life and involving positive affectivity and gratification with a particular brand and constant urges for possessing the brand's products/services, which can be identified by the eleven essential features of acquisitiveness, dependence, follow up, hoard, lack of self-control, obsession, outward influence, persistence within affordability, resistance to substitutes, support and thought occupancy.

"the strength of the bond connecting the brand with the self" (Park et al., 2010; p. 2).

"an evaluative and global measurement capturing how positive and strong the perceived brand assets are from a consumer perspective" (Anselmsson, Johansson, \& Persson, 2008, p.66-67).

"the degree of passionate emotional attachment a satisfied consumer has for a particular trade name" (Caroll and Ahuvia, 2006, p. 81).

"a deeply held commitment to rebuy or repatronize a preferred product/service consistently in the future, thereby causing repetitive same-brand or same brand-set purchasing, despite situational influences and marketing efforts having the potential to cause switching behaviour (Oliver, 1999, p. 34)" (Chaudhuri and Holbrook, 2001, p. 82).

"brand passion as a psychological construct comprised of excitation, infatuation, and obsession for a brand". (Albert et al., 2013, p. 905)

"brand trust as the willingness of the average consumer to rely on the ability of the brand to perform its stated function" (Chaudhuri and Holbrook, 2001, p. 82).

"chronic, repetitive purchasing that becomes a primary response to negative events or feelings" O'Guinn \& Faber 1989, p. 155). 
Table IV.

CFA of the 10-item BASCALE with the calibration and validation samples

\begin{tabular}{|c|c|c|c|c|c|c|c|}
\hline & & \multicolumn{2}{|c|}{$\begin{array}{l}\text { Calibration Sample } \\
\mathrm{CR}=0.92 \\
\mathrm{AVE}=0.54\end{array}$} & & \multicolumn{2}{|c|}{$\begin{array}{l}\text { Validation Sample } \\
C R=0.91 \\
A V E=0.51\end{array}$} & \multirow[b]{2}{*}{$\begin{array}{c}\text { Error } \\
\text { Variance }\end{array}$} \\
\hline & & $\begin{array}{l}\text { Factor } \\
\text { Loading }\end{array}$ & $\begin{array}{l}\text { Item } \\
\text { Reliability }\end{array}$ & $\begin{array}{c}\text { Error } \\
\text { Variance }\end{array}$ & $\begin{array}{l}\text { Factor } \\
\text { Loading }\end{array}$ & $\begin{array}{l}\text { Item } \\
\text { Reliability }\end{array}$ & \\
\hline BA1 & $\begin{array}{l}\text { I try very hard to get } \\
\text { everything from my } \\
\text { favourite brand. }\end{array}$ & 0.54 & 0.30 & 0.70 & 0.56 & 0.31 & 0.69 \\
\hline BA2 & $\begin{array}{l}\text { I often fail to control } \\
\text { myself from purchasing } \\
\text { products of my favourite } \\
\text { brand. }\end{array}$ & 0.68 & 0.46 & 0.54 & 0.63 & 0.39 & 0.61 \\
\hline BA5 & $\begin{array}{l}\text { I often find myself } \\
\text { thinking about my } \\
\text { favourite brand. }\end{array}$ & 0.78 & 0.61 & 0.39 & 0.72 & 0.52 & 0.48 \\
\hline BA6 & $\begin{array}{l}\text { I tend to give up some life } \\
\text { activities and duties such } \\
\text { as the occupational, } \\
\text { academic and familial in } \\
\text { order to fulfil some } \\
\text { activities related to my } \\
\text { favourite brand. }\end{array}$ & 0.74 & 0.54 & 0.46 & 0.69 & 0.47 & 0.53 \\
\hline BA10 & $\begin{array}{l}\text { I tend to allocate certain } \\
\text { portion of my monthly } \\
\text { income to buy the } \\
\text { products of my favourite } \\
\text { brand. }\end{array}$ & 0.80 & 0.63 & 0.37 & 0.74 & 0.54 & 0.46 \\
\hline BA13 & $\begin{array}{l}\text { I usually remember } \\
\text { tenderly the previous } \\
\text { experience with my } \\
\text { favourite brand. }\end{array}$ & 0.65 & 0.43 & 0.57 & 0.73 & 0.53 & 0.47 \\
\hline BA14 & $\begin{array}{l}\text { I experience a state of } \\
\text { impatience immediately } \\
\text { before I can get hold of the } \\
\text { products of my favourite } \\
\text { brand. }\end{array}$ & 0.78 & 0.62 & 0.39 & 0.74 & 0.55 & 0.45 \\
\hline BA15 & $\begin{array}{l}\text { I follow my favourite } \\
\text { brand's news all the time. }\end{array}$ & 0.83 & 0.70 & 0.30 & 0.84 & 0.70 & 0.30 \\
\hline BA16 & $\begin{array}{l}\text { I usually plan when the } \\
\text { next purchase of my } \\
\text { favourite brand will be. }\end{array}$ & 0.78 & 0.60 & 0.40 & 0.71 & 0.51 & 0.49 \\
\hline BA20 & $\begin{array}{l}\text { I would invest my money } \\
\text { in some way to my } \\
\text { favourite brand in order to } \\
\text { support it. }\end{array}$ & 0.69 & 0.48 & 0.52 & 0.71 & 0.51 & 0.49 \\
\hline
\end{tabular}




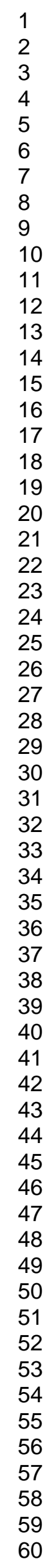


1

2

3

4

5

6

7

8

9

10

11

12

13

14

15

16

17

18

19

20

21

22

23

24

25

26

27

28

29

30

31

32

33

34

35

36

37

38

39

40

41

42

43

44

45

46

47

48

49

50

51

52

53

54

55

56

57

58

59

60
Table V.

Discriminant validity

\begin{tabular}{lllll}
\hline & $\begin{array}{l}\mathrm{BA} \\
(\mathrm{CR}=0.91)\end{array}$ & $\begin{array}{l}\mathrm{BT} \\
(\mathrm{CR}=0.87)\end{array}$ & $\begin{array}{l}\mathrm{AE} \\
(\mathrm{CR}=0.91)\end{array}$ & $\begin{array}{l}\mathrm{LH} \\
(\mathrm{CR}=0.91)\end{array}$ \\
\hline $\mathrm{BA}$ & $\mathbf{0 . 5 5}$ & 0.10 & 0.02 & 0.02 \\
$\mathrm{BT}$ & 0.32 & $\mathbf{0 . 6 3}$ & 0.00 & 0.00 \\
$\mathrm{AE}$ & 0.14 & 0.04 & $\mathbf{0 . 6 6}$ & 0.00 \\
$\mathrm{LH}$ & 0.15 & 0.05 & 0.02 & $\mathbf{0 . 6 8}$
\end{tabular}

Notes: Correlations are below the diagonal, squared correlations are above the diagonal, and AVE estimates are presented on the diagonal. 
Table VI.

T-Score of BASCALE

\begin{tabular}{|c|c|c|c|c|c|}
\hline Raw score & T-score & Frequency & Raw score & T-score & Frequency \\
\hline 10.00 & 33.48 & 13 & 39.00 & 56.00 & 12 \\
\hline 11.00 & 34.26 & 4 & 40.00 & 56.78 & 23 \\
\hline 12.00 & 35.03 & 11 & 41.00 & 57.56 & 9 \\
\hline 13.00 & 35.81 & 19 & 42.00 & 58.33 & 9 \\
\hline 14.00 & 36.59 & 16 & 43.00 & 59.11 & 14 \\
\hline 15.00 & 37.36 & 13 & 44.00 & 59.89 & 11 \\
\hline 16.00 & 38.14 & 14 & 45.00 & 60.66 & 10 \\
\hline 17.00 & 38.92 & 17 & 46.00 & 61.44 & 10 \\
\hline 18.00 & 39.69 & 11 & 47.00 & 62.22 & 5 \\
\hline 19.00 & 40.47 & 14 & 48.00 & 62.99 & 2 \\
\hline 20.00 & 41.25 & 16 & 49.00 & 63.77 & 9 \\
\hline 21.00 & 42.02 & 11 & 50.00 & 64.55 & 3 \\
\hline 22.00 & 42.80 & 21 & 51.00 & 65.32 & 6 \\
\hline 23.00 & 43.58 & 13 & 52.00 & 66.10 & 10 \\
\hline 24.00 & 44.35 & 13 & 53.00 & 66.88 & 5 \\
\hline 25.00 & 45.13 & 15 & 54.00 & 67.65 & 6 \\
\hline 26.00 & 45.91 & 11 & 55.00 & 68.43 & 8 \\
\hline 27.00 & 46.68 & 18 & 56.00 & 69.21 & 2 \\
\hline 28.00 & 47.46 & 17 & 57.00 & 69.98 & 3 \\
\hline 29.00 & 48.24 & 20 & 58.00 & 70.76 & 6 \\
\hline 30.00 & 49.01 & 13 & 59.00 & 71.54 & 1 \\
\hline 31.00 & 49.79 & 11 & 60.00 & 72.31 & 1 \\
\hline 32.00 & 50.57 & 15 & 61.00 & 73.09 & 1 \\
\hline 33.00 & 51.34 & 18 & 62.00 & 73.87 & 1 \\
\hline 34.00 & 52.12 & 20 & 63.00 & 74.64 & 2 \\
\hline 35.00 & 52.90 & 16 & 66.00 & 76.97 & 1 \\
\hline 36.00 & 53.67 & 16 & 68.00 & 78.53 & 1 \\
\hline 37.00 & 54.45 & 20 & 69.00 & 79.30 & 1 \\
\hline 38.00 & 55.23 & 15 & 70.00 & 80.08 & 1 \\
\hline Statistics & & \multicolumn{2}{|c|}{ Raw score } & \multicolumn{2}{|c|}{ T-score } \\
\hline & $\mathbf{N}$ & \multicolumn{2}{|c|}{604} & \multicolumn{2}{|c|}{604} \\
\hline & Mean & \multicolumn{2}{|c|}{31.27} & \multicolumn{2}{|c|}{50.00} \\
\hline & Median & \multicolumn{2}{|c|}{31.00} & \multicolumn{2}{|c|}{49.79} \\
\hline & Std. Deviation & \multicolumn{2}{|c|}{12.88} & \multicolumn{2}{|c|}{10.00} \\
\hline & Minimum & \multicolumn{2}{|c|}{10.00} & \multicolumn{2}{|c|}{33.48} \\
\hline & Maximum & \multicolumn{2}{|c|}{70.00} & \multicolumn{2}{|c|}{80.08} \\
\hline & Percentiles 25 & \multicolumn{2}{|c|}{21.00} & \multicolumn{2}{|c|}{42.02} \\
\hline & $\mathbf{5 0}$ & \multicolumn{2}{|c|}{31.00} & \multicolumn{2}{|c|}{49.79} \\
\hline & 75 & \multicolumn{2}{|c|}{40.00} & \multicolumn{2}{|c|}{56.78} \\
\hline
\end{tabular}

Notes: Raw score scaling: 1 (not true at all) to 7 (very true). T-score mean: 50 (corresponding to raw score 31-32). 